\title{
CORRECTION
}

\section{Correction to: Creep and Long-Term Permeability of a Red Sandstone Subjected to Cyclic Loading After Thermal Treatments}

\author{
Sheng-Qi Yang ${ }^{1}$ (D) Bo Hu$^{1}$
}

Published online: 24 September 2018

๑) Springer-Verlag GmbH Austria, part of Springer Nature 2018

\section{Correction to: Rock Mechanics and Rock Engineering https://doi.org/10.1007/s00603-018-1528-8}

In Figs. 14 and 15, the unit $\left(\mathrm{m}^{2}\right)$ of permeability $(k)$ is mistaken, which should be replaced with $\left(10^{-6} \mathrm{~m}^{2}\right)$.

Publisher's Note Springer Nature remains neutral with regard to jurisdictional claims in published maps and institutional affiliations.

The original article can be found online at https://doi.org/10.1007/ s00603-018-1528-8.

Sheng-Qi Yang yangsqi@hotmail.com

1 State Key Laboratory for Geomechanics and Deep Underground Engineering, School of Mechanics and Civil Engineering, China University of Mining and Technology, Xuzhou 221116, People's Republic of China 